\title{
Association of Seed Traits with Fruit Yield in Cucumber (Cucumis sativus L.)
}

\author{
Saheb Pal ${ }^{1,2 *}$, Hem Raj Sharma ${ }^{2}$, Ashok Kumar Thakur ${ }^{3}$ and Rajesh Kumar Dogra ${ }^{4}$ \\ ${ }^{1}$ Division of Vegetable Crops, ICAR- Indian Institute of Horticultural Research, \\ Hesaraghatta, Bengaluru, Karnataka-560089, India \\ ${ }^{2}$ Department of Vegetable Science, ${ }^{4}$ Department of Fruit Science, Dr YS Parmar University of \\ Horticulture and Forestry, Nauni, Solan, HP-173230, India \\ ${ }^{3}$ Krishi Vigyan Kendra-Rohru, Shimla; Dr YS Parmar University of Horticulture and \\ Forestry, Shimla, HP-171207, India \\ *Corresponding author
}

\section{A B S T R A C T}

\section{Keywords}

Cucumber,

Correlation, Indirect

selection, Seed

Traits, Yield

\section{Article Info}

Accepted:

24 January 2018

Available Online:

10 February 2018
With the objective to find the association of different seed characters with fruit yield in cucumber, an experiment was conducted with 30 indigenous genotypes, collected from five different states, at the Experimental Farm of the Department of Vegetable Science, Dr YS Parmar University of Horticulture and Forestry, Nauni, Solan during Kharif, 2015. Results revealed that yield per plant had positive and significant association with all the seed characters under study viz., seed length, seed breadth, hundred seed weight, germination percentage, seed vigour index-I and seed vigour index-II. The success or failure of any crop production programme depends largely upon the potential and quality of the seed, which is regarded as the most important input in agriculture. From our results, it is suggested to carry out indirect selection for these seed traits in order to improve fruit yield in cucumber.

\section{Introduction}

Cucumber (Cucumis sativus L.) is one of the most important Cucurbitaceous vegetable crops grown in India. It ranks fourth among most important vegetable crops of Asia after tomato, cabbage and onion (Tatlioglu, 1993). Cucumbers is mainly valued for its immature fruits, eaten raw as salad, believed to have cooling effects on our body and are considered good for people suffering from constipation, jaundice and indigestion. In India, it is grown in open field as well as protected conditions to meet the domestic demands as well as for export. Although India is considered as the primary centre of origin of cucumber, very less attention has been paid for its genetic improvement. As a result, a considerable gap is observed between the expected and the actual yield of this crop.

Yield, being a complex and polygenic character, is often difficult to improve through direct selection for a particular trait as the final 
yield depends upon the interrelationship of a number of attributing traits. Generally, it is stated that healthier the seed, better will be the yield but in this regard, much information is not available, especially regarding seed selection in cucumber for a better harvest. Therefore, the present study was undertaken to estimate the nature and magnitude of association among different seed traits with fruit yield in cucumber by using variance and covariance matrix as suggested by Al-Jibouri et al., (1958).

\section{Materials and Methods}

The present study was conducted at the Experimental Farm of the Department of Vegetable Science, Dr YS Parmar University of Horticulture and Forestry, Nauni, Solan, Himachal Pradesh, during Kharif, 2015. The experimental materials comprised of thirty indigenous cucumber genotypes collected from five different states of the country (Table 1). The experiment was laid out in a Randomized Complete Block Design (RCBD) with three replications at a spacing of $125 \mathrm{~cm}$ $\times 50 \mathrm{~cm}$, keeping ten plants in each replication in each entry.

Standard cultural practices recommended in the Package and Practices for Vegetable Crops were followed to ensure a healthy crop stand (Anonymous, 2013). Data were recorded for six important seed traits viz., seed length (mm), seed breadth ( $\mathrm{mm})$, hundred seed weight $(\mathrm{g})$, germination percentage, seed vigour index-I and II and yield per plant $(\mathrm{kg})$. Seed length and seed breadth were recorded with the help of a digital Vernier caliper from 10 randomly selected self-pollinated seeds of each genotype in each replication. Seed germination of the self-pollinated seeds was tested in the laboratory by adopting the standard method of International Seed Testing Association (Anonymous, 1985) and seed vigour index-I and II were calculated as per the formula of Abdul-Baki and Anderson (1973), where, seed vigour index-I = germination percentage $\times$ seedling length $(\mathrm{cm})$ and seed vigour index-II = germination percentage $\times$ seedling dry weight $(\mathrm{mg})$. The genotypic and phenotypic correlations were calculated as per Al-Jibouri et al., (1958) by using OPSTAT software (Sheoran et al., 1998).

\section{Results and Discussion}

Analysis of variance, presented in Table 2, indicated presence of significant differences among all the genotypes for all the seven characters under study. These differences indicated the presence of enormous variability in the studied germplasm that had ample scope for genetic improvement on the basis of seed selection in cucumber. The phenotypic and genotypic correlation coefficients among the seed characters and yield per plant have been presented in Table 3.

The genotypic correlation coefficients were higher in magnitude than the corresponding phenotypic correlation coefficients, indicating that the expression of these characters had a strong genetic backup and not merely due to the prevailing environment. The results revealed that seed vigour index-I had the strongest significant association with yield both at genotypic (0.966) and phenotypic (0.959) levels followed by seed vigour indexII (0.946, 0.872 respectively). Furthermore, yield per plant had significant positive association at both genotypic and phenotypic levels with germination percentage $(0.554$, $0.554)$, seed breadth $(0.538,0.465)$, seed length $(0.469,0.445)$ and hundred seed weight $(0.285,0.274)$. Moreover, the studied seed traits had positive significant correlations with each other except for seed germination percentage which was not correlated with three seed traits viz., seed length, seed breadth and hundred seed weight. 
Table.1 List of cucumber genotypes under study along with their sources

\begin{tabular}{|l|l|l|l|}
\hline Genotypes & \multicolumn{1}{|c|}{ Sources } & \multicolumn{1}{c|}{ Genotypes } & \multicolumn{1}{c}{ Sources } \\
\cline { 1 - 1 } LC-1 & Jampur, Hooghly, WB & LC-16 & Uluberia, Howrah, WB \\
\hline LC-2 & Maheshwarpur, Hooghly, WB & LC-17 & Mangalbaria, Sikkim \\
\hline LC-3 & Sheoraphully, Hooghly, WB & LC-18 & Allahabad, UP \\
\hline LC-4 & Champadanga, Hooghly, WB & LC-19 & Varanasi, UP \\
\hline LC-5 & Bhanderhati, Hooghly, WB & LC-20 & Hubli, Dharwad, KN \\
\hline LC-6 & Sibaichandi, Hooghly, WB & LC-21 & $\begin{array}{l}\text { Ettinagudda, } \\
\text { KN Darwad, }\end{array}$ \\
\hline LC-7 & Harit, Hooghly, WB & LC-22 & Bhuira, Sirmour, HP \\
\hline LC-8 & Gopalpur, Nadia, WB & LC-23 & Narag, Sirmour, HP \\
\hline LC-9 & Simurali, Nadia, WB & LC-24 & Gohar, Mandi, HP \\
\hline LC-10 & Barasat, N-24 Parganas, WB & LC-25 & Manali, Kullu, HP \\
\hline LC-11 & Amtala, S-24 Parganas, WB & LC-26 & Sarkaghat, Mandi, HP \\
\hline LC-12 & Kamdebpur, N-24 Parganas, WB & LC-27 & Deothi, Solan, HP \\
\hline LC-13 & Memari, Burdwan, WB & LC-28 & Joharji, Solan, HP \\
\hline LC-14 & $\begin{array}{l}\text { Diamond Harbour, S-24 Parganas, } \\
\text { WB }\end{array}$ & LC-29 & Bhojnagar, Solan, HP \\
\hline LC-15 & Paskura, West Medinipur, WB & K-75 & UHF, Nauni, Solan, HP \\
\hline
\end{tabular}

Table.2 Analysis of Variance of different seed characters and yield per plant in cucumber

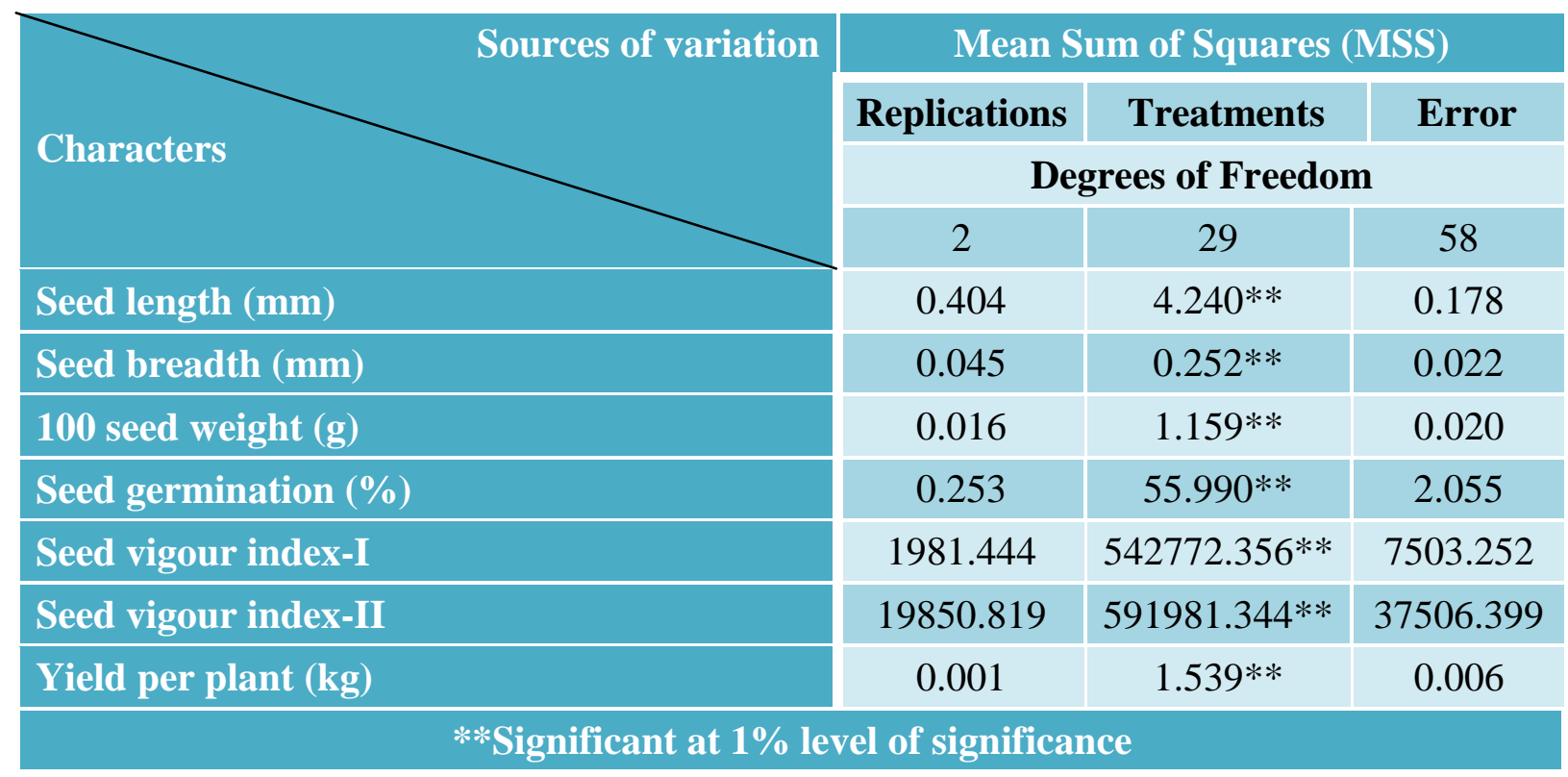


Table.3 Correlation coefficients of different seed characters and yield per plant in cucumber

\begin{tabular}{|c|c|c|c|c|c|c|c|}
\hline & $\begin{array}{c}\text { Seed } \\
\text { length }\end{array}$ & $\begin{array}{c}\text { Seed } \\
\text { Breadth }\end{array}$ & $\begin{array}{c}\mathbf{1 0 0} \\
\text { Seed } \\
\text { Weight }\end{array}$ & $\begin{array}{c}\text { Germination } \\
\%\end{array}$ & $\begin{array}{c}\text { Seed } \\
\text { Vigour } \\
\text { Index-I }\end{array}$ & $\begin{array}{c}\text { Seed } \\
\text { Vigour } \\
\text { Index-II }\end{array}$ & $\begin{array}{c}\text { Yield } \\
\text { Per } \\
\text { Plant }\end{array}$ \\
\hline Seed length & $\mathbf{1 . 0 0 0}$ & $0.850^{* *}$ & $0.619^{* *}$ & -0.125 & $0.468^{* *}$ & $0.431^{* *}$ & $0.469^{* *}$ \\
\hline Seed Breadth & $0.729^{* *}$ & $\mathbf{1 . 0 0 0}$ & $0.576^{* *}$ & 0.152 & $0.567^{* *}$ & $0.526^{* *}$ & $0.538^{* *}$ \\
\hline $\begin{array}{c}\text { 100 Seed } \\
\text { Weight }\end{array}$ & $0.553^{* *}$ & $0.494^{* *}$ & $\mathbf{1 . 0 0 0}$ & -0.091 & $0.337^{* *}$ & $0.342^{* *}$ & $0.285^{* *}$ \\
\hline $\begin{array}{c}\text { Germination } \\
\text { \% }\end{array}$ & -0.101 & 0.112 & -0.084 & $\mathbf{1 . 0 0 0}$ & $0.621^{* *}$ & $0.657^{* *}$ & $0.554^{* *}$ \\
\hline $\begin{array}{c}\text { Seed Vigour } \\
\text { Index-I }\end{array}$ & $0.432^{* *}$ & $0.478^{* *}$ & $0.320^{* *}$ & $0.632^{* *}$ & $\mathbf{1 . 0 0 0}$ & $0.938^{* *}$ & $0.966^{* *}$ \\
\hline $\begin{array}{c}\text { Seed Vigour } \\
\text { Index-II }\end{array}$ & $0.379^{* *}$ & $0.384^{* *}$ & $0.292^{* *}$ & $0.600^{* *}$ & $0.865^{* *}$ & $\mathbf{1 . 0 0 0}$ & $0.946^{* *}$ \\
\hline $\begin{array}{c}\text { Yield Per } \\
\text { Plant }\end{array}$ & $0.445^{* *}$ & $0.465^{* *}$ & $0.274^{* *}$ & $0.554^{* *}$ & $0.959^{* *}$ & $0.872^{* *}$ & $\mathbf{1 . 0 0 0}$ \\
\hline $\begin{array}{c}* * \text { Significant at 1\% level of significance. Genotypic correlation coefficients }=\text { upward right side of diagonal; } \\
\text { Phenotypic correlation coefficients = downward left side of diagonal }\end{array}$
\end{tabular}

The success or failure of any crop production programme depends largely upon the potential and quality of the seed. Estimation of such parameters viz., seed vigour index-I and seed vigour index-II require a sufficient number of seeds and lab facilities, which may not be available at the field or farmers' level. The traits viz., seed length, seed breadth and hundred seed weight are easily observable at both breeders' as well as farmers' end. In our study, these three traits had positive and significant association with yield per plant as well as with seed vigour index-I and seed vigour index-II. Therefore, indirect selection for yield can be mediated through these traits in cucumber by the breeders as well as by the farmers. Similar correlations of yield with various seed traits were also reported by Rastogi and Rathore (1990), Singh (1997), Kumar et al., (2008), Yadav et al., (2010), Bhardwaj and Kumar (2012) and Veena et al., (2013).

Cucumber, being indigenous to Indian subcontinent, enormous variability exists in Indian germplasm for different morphoagronomic traits. As it belongs to family
Cucurbitaceae, members of which suffer from negligible inbreeding depression, as a breeding method, individual plant selection has become popular among the breeders. Therefore, while conducting selection for yield, based on our results, greater emphasis might be given for selecting the genotypes having longer, broader and heavier seeds, which will give rise to vigourous plants and that will ultimately ensure a better harvest.

\section{Acknowledgement}

The authors are thankful to all the staffs of the Department of Vegetable Science, Dr YS Parmar University of Horticulture and Forestry, Nauni, Solan, Himachal Pradesh for providing all the necessary facilities during the research trial and lab work.

\section{References}

Abdul-Baki, A. A., and Anderson, J. D. 1973. Vigour germinated in soybean seed by multiple criteria. Crop Science. 13, 630633.

Al-Jobouri, H. W., Miller, P. A., and 
Robinson, H. F. 1958. Genotypic and environmental variances and covariances in an upland cotton cross of interspecific origin. Agronomy Journal. 50, 633-636.

Anonymous. 1985. International Rules for Seed Testing. Seed Science and Technology. 13, 293-353.

Anonymous. 2013. Package of Practices for Vegetable Crops. Directorate of Extension Education, Dr YS Parmar University of Horticulture and Forestry, Nauni, Solan. 202 p.

Bhardwaj, R. K., and Kumar, S. 2012. Studies on correlation between yield and seed characters in cucumber (Cucumis sativus L.). International Journal of Farm Sciences. 2(1), 54-58.

Kumar, A., Kumar, S. and Pal, A. K. 2008. Genetic variability and character association for fruit yield and yield traits in cucumber. Indian Journal of Horticulture. 65(4), 423-428.

Rastogi, K. B., and Rathore, A. D. 1990. A note on interrelationship between yield and important plant characters of cucumber. Vegetable Science. 17(1), 102-104.

Sheoran, O. P., Tonk, D. S., Kaushik, L. S., Hasija, R. C., and Pannu, R. S. 1998. Statistical software package for agricultural research workers. In: Recent Advances in Information Theory, Statistics and Computer Applications. (Eds.). Hooda, D. S., and Hasija, R. C. Department of Mathematics and Statistics, Chaudhary Charan Singh Haryana Agricultural University, Hisar, Haryana. pp. 139143.

Singh, M. 1997. Variability studies in some lines of cucumber (Cucumis sativus L.). M.Sc. Thesis, Department of Vegetable Science, Dr YS Parmar University of Horticulture and Forestry, Nauni, Solan, Himachal Pradesh, India.

Tatlioglu, T. 1993. Cucumber (Cucumis sativus L.) In: Kailor, G., and Bergn, B. (Eds.). Genetic Improvement of Vegetable Crops. Oxford Pergamon Press, Oxford. pp. 197-227.

Veena, R., Sidhu, A. S., Pitchaimuthu, M., and Souravi, K. 2013. Character association for fruit yield and yield traits in cucumber (Cucumis sativus L.). Electronic Journal of Plant Breeding. 4(1), 1108-1112.

Yadav, Y. C., Kumar, S., and Singh, R. 2010. Correlation coefficient and path analysis in cucumber (Cucumis sativus L.). Progressive Horticulture. 42(1), 71-7.

\section{How to cite this article:}

Saheb Pal, Hem Raj Sharma, Ashok Kumar Thakur and Rajesh Kumar Dogra. 2018. Association of Seed Traits with Fruit Yield in Cucumber (Cucumis sativus L.). Int.J.Curr.Microbiol.App.Sci. 7(02): 2692-2696. doi: https://doi.org/10.20546/ijcmas.2018.702.326 